\title{
Pb-Stress Induced Oxidative Stress Caused Alterations in Antioxidant Efficacy in Two Groundnut (Arachis hypogaea L.) Cultivars
}

\author{
Ambekar Nareshkumar, G. V. Nagamallaiah, M. Pandurangaiah, K. Kiranmai, \\ V. Amaranathareddy, U. Lokesh, B. Venkatesh, Chinta Sudhakar* \\ Plant Molecular Biology Unit, Department of Botany, Sri Krishnadevaraya University, Anantapur, India \\ Email: ${ }^{*}$ chintasudhakar@yahoo.com
}

Received 23 August 2015; accepted 26 October 2015; published 29 October 2015

Copyright @ 2015 by authors and Scientific Research Publishing Inc.

This work is licensed under the Creative Commons Attribution International License (CC BY).

http://creativecommons.org/licenses/by/4.0/

(c) (i) Open Access

\section{Abstract}

Lead $(\mathrm{Pb})$ is an important environmental pollutant extremely toxic to plants and other living organisms including humans. To assess $\mathrm{Pb}$ phytotoxicity, a pot culture experiment was carried out using two groundnut cultivars (Arachis hypogaea L. cultivar K6 and cultivar K9) on plant growth, ROS levels, lipid peroxidation, and antioxidant metabolism using biochemical, histochemical methods. Plants were grown in pots for 14 days, in the botanic garden, and subjected to $\mathrm{Pb}$-stress $(0,100,200,400$ and $800 \mathrm{ppm})$ by adding $\mathrm{Pb}\left(\mathrm{NO}_{3}\right)_{2}$ solution and further allowed to grow for 10 days. The results showed that cultivar $\mathrm{K} 6$ registered lower $\mathrm{Pb}$ accumulation than cultivar K9, however, localization of $\mathrm{Pb}$ was greater in roots than leaves in both groundnut cultivars. The $\mathrm{Pb}$-stress results in an increase in free radicals $\left(\mathrm{O}_{2}{ }^{\circ}-\right.$ and $\left.\mathrm{H}_{2} \mathrm{O}_{2}\right)$ generation in both groundnut cultivars, but more significantly in cultivar $\mathrm{K9}$ than $\mathrm{K6}$. Pb-stress also caused significant changes in the rate of peroxidation as shown in the levels of malondialdehyde (MDA) content in roots and leaves of both groundnut cultivars. Free proline, ascorbic acid (AsA) and non-protein thiol (NP-SH) contents were increased in cultivar $\mathrm{K} 6$ due to $\mathrm{Pb}$-stress, but less in cultivar $\mathrm{K9}$. $\mathrm{Pb}$ treated plants showed increased levels of antioxidant enzymes such as superoxide dismutase (SOD), guaiacol peroxidase (GPX), ascorbate peroxidase (APX) glutathione reductase (GR) and glutathione Stransferase (GST). Isozyme band intensities of SOD, GPX and APX were more consistent with the respective changes in antioxidative enzyme activities. These results indicate that cultivar $\mathrm{K} 6$ possesses greater tolerance potential for $\mathrm{Pb}$ toxicity than cultivar $\mathrm{K} 9$.

\section{Keywords}

Groundnut (Arachis hypogaea L.), Pb-Stress, Oxidative Stress, Antioxidant Enzymes, Non-Protein Thiols, Reactive Oxygen Species

\footnotetext{
*Corresponding author.
}

How to cite this paper: Nareshkumar, A., et al. (2015) Pb-Stress Induced Oxidative Stress Caused Alterations in Antioxidant Efficacy in Two Groundnut (Arachis hypogaea L.) Cultivars. Agricultural Sciences, 6, 1283-1297. 


\section{Introduction}

In recent years heavy metal pollution has become one of the serious environmental problems worldwide. Unlike organic pollutants that can be easily degradable to harmless small molecules, toxic elements, such as lead, mercury, cadmium, copper and zinc, are immutable by biochemical reactions [1], hence, it is difficult to remediate these metals form the soil and water. The hot spots of soil contamination are located in the regions of large industrial activities, where surrounding agricultural lands are affected by the deposition of heavy metals and also agricultural practice, e.g., application of sewage sludges, phosphate fertilizers, liming, irrigation water and pesticides has lead to increased heavy metal concentration in soils [2]. The long time persistent nature of some heavy metals, such as $\mathrm{Pb}$ and $\mathrm{Cd}$ are leading to hazardous accumulation [3], and a huge variation in metal tolerance was observed between different crop plants [4] [5].

Among heavy metal ions, $\mathrm{Pb}$ is one of the most hazardous pollutants of the environment and $\mathrm{Pb}$ pollution in air, water and agricultural soil is an ecological concern due to its extreme impact on human health and environment. Naturally $\mathrm{Pb}$ occurs in soils, but in relatively low concentrations, in uncontaminated soils in the range of 2 to $200 \mathrm{ppm}$ dry weight, whereas $0.1-10 \mathrm{ppm}$ dry weight in agricultural crops [3]. The effect of Pb mainly depends on concentration, soil type, soil properties and plant species [6]. Heavy metal induced phytotoxicity or plant tolerant responses to heavy metal stress is a complex phenomenon, involving developmental changes as well as physiological and biochemical mechanisms [5] [7] [8].

Lead $(\mathrm{Pb})$ is reported to produce reactive oxygen species (ROS) and enhance antioxidant enzyme activity in plants [9]. ROS production includes harmful effects in plant cells, such as inhibition of photosynthetic activity, inhibition of ATP production, lipid peroxidation and DNA damage [1]. In addition, enhanced production of ROS which causes damage to cell membranes, nucleic acids and chloroplast pigments [10], is a major consequence. Different ROS including superoxide anion $\left(\mathrm{O}_{2}{ }^{-}{ }^{-}\right)$, singlet oxygen $\left({ }^{1} \mathrm{O}_{2}\right)$, hydrogen peroxide $\left(\mathrm{H}_{2} \mathrm{O}_{2}\right)$ and the hydroxyl radical $\left(\mathrm{OH}^{\bullet}\right)$, that have been proven to be important agents in the origin of tissue injury and membrane damage, are produced after the exposure of plants to heavy metals [11] [12]. Generation of excess ROS in heavy metal stressed plants may be a consequence of the distribution of the balance between their production and decomposition by antioxidant enzyme activities composed of antioxidants, such as superoxide dismutase (SOD), catalase (CAT) ascorbate peroxidise (APX) and guaiacol peroxidise (GPX) and glutathione reductase (GR) and the non-enzymatic antioxidants such as reduced glutathione (GSH), ascorbic acid (AsA) [1] [13]-[17]. Plants can tolerate $\mathrm{Pb}$ by chelation of the metal ions and compartmentalization into the vacuole [18]. It has also been shown that non-protein thiols (NP-SH) and glutathione (GSH) are known to play a pivotal role in metal detoxification mechanisms in terrestrial plants [19] [20]. In addition, phytochelatin complex metal ions through the thiolic group (-SH) of Cys and the PC-Cd complexes are found to be accumulated in the vacuole through the activity of ABC transporters, thereby limiting the free Cd inside the cytosol [21].

The effect of Pb-stress has been studied in various plant species including Eichhornia crassipes [1], Oryza sativa [14], Sesbania drummondii [22], Triticum aestivum [23], Sesuvium portulacastrum and Brassica juncea [24], Salsola passerine and Chenpodium album [25], and some Chinese groundnut cultivars [26]. Though, the groundnut (Arachis hypogaea L.) species has the potential for hyperaccumulation of various heavy metals, the effect of $\mathrm{Pb}$ exposure induced physiological and biochemical changes in this plant has not been studied yet. Earlier studies demonstrated that some groundnut cultivars were tolerant to heavy metals like $\mathrm{Cd}$ and $\mathrm{Pb}$ [26] [27]. Although, legumes are reported to be tolerant to some heavy metals [6] [28], there has been a considerable need in finding suitable groundnut cultivars that are able to grow on heavy metal contaminated soils for land reclamation and to study metal tolerance mechanisms exists in this crop. Owing to the economic importance of groundnut crop, and increasing international concern on the soil contaminations due to $\mathrm{Cd}$, and $\mathrm{Pb}$ [29], it is very important to investigate the impacts of heavy metals on growth, physiological and biochemical aspects in groundnut under induced Pb-stress. This crop may further be useful in soil reclamation through the process of phytoremediation. However, selection of cultivars would be of great importance to reclaim the soil with lesser impact on plant metabolism. So far this plant species has been used in studies of the effects of heavy metals like Cd [26], and $\mathrm{Pb}$ [30], on metal accumulation and yield study parameters. In addition, there are no publications on the relationship between $\mathrm{Pb}$ toxicity and morphological, physiological and antioxidative responses of groundnuts. In this study, we initially aimed to investigate $\mathrm{Pb}$ induced tolerance mechanisms in two widely cultivated, local and high yielding groundnut cultivars (cultivar K6 and K9) subjected to Pb-stress. Therefore, we studied in detail about the role of antioxidant systems in detoxification of $\mathrm{Pb}$ ions in groundnut under pot culture experiment. 


\section{Materials and Methods}

\subsection{Plant Material and $\mathrm{Pb}$ Treatment}

Groundnut (cultivar K6 and K9) seeds were procured from Regional Agricultural Research Station (RARS), Kadiri, India, was sown in earthen pots containing air dried red soil and farmyard manure in 3:1 proportion. The pots were kept under natural photoperiod $\left(12-14 \mathrm{~h}\right.$ and temperature $\left.28^{\circ} \mathrm{C} \pm 4^{\circ} \mathrm{C}\right)$ in the botanical garden and were irrigated once a day with water and maintained for 14 days. Fourteen-day-old plants were subjected to $\mathrm{Pb}$-stress once by adding 0 (control), 100, 200, 400 and $800 \mathrm{ppm}$ of $\mathrm{Pb}$ solution using lead nitrate $\left(\mathrm{Pb}\left(\mathrm{NO}_{3}\right)_{2}\right)$. For each treatment, twenty five pots, each with three plants were maintained. Both control and treated pots were irrigated daily with tap water. Care was taken while adding water slightly less than field capacity (approximately $300 \mathrm{ml}$ ) to avoid leaching out of solution from treated pots. After 10 days of stress imposition, the plants were uprooted carefully; the leaves and roots were separated, flash frozen in liquid nitrogen and stored at $-80^{\circ} \mathrm{C}$ until further use.

\subsection{Growth Parameters}

The plants were carefully uprooted from pots and washed thoroughly with running tap water. Plant growth was determined by measuring the length of the root and shoot system. The dry weight (DW) was measured after the shoots and roots were dried at $80^{\circ} \mathrm{C}$ to constant weight.

\subsection{In Situ Histochemical Localization of $\mathrm{O}_{2}{ }^{-}$and $\mathrm{H}_{2} \mathrm{O}_{2}$}

In situ accumulation of $\mathrm{O}_{2}{ }^{\bullet-}$ and $\mathrm{H}_{2} \mathrm{O}_{2}$ was detected by histochemical staining with nitrobluetetrazolium (NBT) and diaminobenzidine (DAB) according to Romero-Puertas et al. [31], with minor modifications. For $\mathrm{O}_{2}{ }^{\bullet-}$ detection the leaves of control and $\mathrm{Pb}$-stressed plants were excised and immersed in a $0.1 \%$ solution of NBT in 10 $\mathrm{mM}$ phosphate buffer ( $\mathrm{pH}$ 7.8) at room temperature. The immersed leaves were illuminated for 1 - $2 \mathrm{~h}$ until the appearance of dark spots, characteristic of blue formazan precipitates. For localization of $\mathrm{H}_{2} \mathrm{O}_{2}$, excised leaves were immersed in a $0.1 \% \mathrm{DAB}$ solution in $10 \mathrm{mM}$ phosphate buffer $(\mathrm{pH} 3.8$ ) and incubated at room temperature for $8 \mathrm{~h}$ until brown spots, derived from the reaction of $\mathrm{DAB}$ with $\mathrm{H}_{2} \mathrm{O}_{2}$. The leaves were then bleached in warm ethanol to visualize the blue and brown spots.

\subsection{Superoxide Anion $\left(\mathrm{O}_{2}{ }^{\circ}\right)$ Estimation}

Superoxide anion content was determined using the method described by Doke [32]. The leaves were cut into pieces and placed in the test tubes and filled with $7 \mathrm{ml}$ of mixture containing $50 \mathrm{mM}$ of $\mathrm{NaN}_{3}$. Next, the test tubes were incubated in dark for $5 \mathrm{~min}$, and then $2 \mathrm{ml}$ of the solution were taken from the tubes and heated up for $15 \mathrm{~min}$ at $85^{\circ} \mathrm{C}$. The samples were cooled down on ice for $5 \mathrm{~min}$ and the absorbance was measured at 580 $\mathrm{nm}$ against the control.

\subsection{Hydrogen Peroxide $\left(\mathrm{H}_{2} \mathrm{O}_{2}\right)$ Estimation}

$\mathrm{H}_{2} \mathrm{O}_{2}$ levels were determined according to Singh et al. [33]. Fresh leaves ( $\left.0.1 \mathrm{~g}\right)$ were homogenised in ice bath with $5 \mathrm{ml} 0.1 \%(\mathrm{w} / \mathrm{v})$ trichloroacetic acid (TCA). The homogenate was centrifuged at 12,000 $\times \mathrm{g}$ for $15 \mathrm{~min}$ and $0.5 \mathrm{ml}$ of the supernatant was added to $0.5 \mathrm{ml} 10 \mathrm{mM}$ potassium phosphate buffer (pH 7.0) and $1 \mathrm{ml}$ of $1 \mathrm{M} \mathrm{KI}$. $\mathrm{H}_{2} \mathrm{O}_{2}$ was used as a standard and the concentration of $\mathrm{H}_{2} \mathrm{O}_{2}$ in the samples was calculated and expressed in $\mu \mathrm{mol} \cdot \mathrm{g}^{-1}$ dry weight.

\subsection{Lipid Peroxidation}

The level of lipid peroxidation products was determined by estimating thiobarbituric acid reactive substances (TBARS) as described by Hodges et al. [34]. Five hundred milligrams of leaf tissue was ground to a fine paste with $15 \mathrm{ml}$ of ethanol: water ( $95: 5 \mathrm{v} / \mathrm{v}$ and $0.1 \%$ butylated hydroxyl toluene). The contents were centrifuged at $3000 \times \mathrm{g}$ for $10 \mathrm{~min}$ and the supernatant was collected. One millilitre of supernatant was treated with $1 \mathrm{ml}$ of $20 \%$ TCA along with $0.65 \%$ thiobarbituric acid (TBA) in a clean glass tube and mixed thoroughly. Another $1 \mathrm{ml}$ of supernatant was treated only with $1 \mathrm{ml}$ of $20 \%$ TCA and mixed thoroughly. The mixtures were heated at $95^{\circ} \mathrm{C}$ 
for $30 \mathrm{~min}$ in a water bath, cooled immediately on ice and centrifuged at $3000 \times \mathrm{g}$ for $10 \mathrm{~min}$. Absorbance at $532 \mathrm{~nm}$ was recorded for MDA. In addition, the absorbance at $440 \mathrm{~nm}$ (carbohydrates) and $600 \mathrm{~nm}$ (phenylpropanoid pigments) were also recorded to avoid overestimation of MDA.

$\left[\left(\mathrm{Abs}_{532}+\mathrm{TBA}\right)-\left(\mathrm{Abs}_{600}+\mathrm{TBA}\right)-\left(\mathrm{Abs}_{532}-\mathrm{TBA}\right)-\left(\mathrm{Abs}_{600}-\mathrm{TBA}\right)\right]=\mathrm{A}$.

$\left[\left(\mathrm{Abs}_{440+\mathrm{TBA}}-\mathrm{Abs}_{600+\mathrm{TBA}}\right) 0.0571\right]=\mathrm{B}$.

[MDA equivalents $\left.\left(\mu \mathrm{mol} \cdot \mathrm{ml}^{-1}\right)=(\mathrm{A}-\mathrm{B} / 157000) 10^{3}\right]=\mathrm{C}$.

MDA equivalents $\left(\mu \mathrm{mol} \cdot \mathrm{g}^{-1}\right)=(\mathrm{C} \times 15 \times 1 / 0.5)$.

\subsection{Free Proline Content}

The extraction and estimation of free proline was done according to Bates et al. [35]. Fresh plant material (0.5 g) was homogenized in a pre-chilled mortar with a pestle using 3\% aqueous sulfosalicylic acid. The homogenate was filtered through four layered muslin cloth and the filtrate was collected. The extraction was repeated twice, all the filtrates were pooled and made up to known volume. Two millilitres of filtrate was taken into a test tube and $2 \mathrm{ml}$ of acid ninhydrin, $2 \mathrm{ml}$ of glacial acetic acid were added. The tubes were incubated at $100^{\circ} \mathrm{C}$ for $1 \mathrm{~h} \mathrm{in}$ a boiling water bath. The tubes, after incubation, were transferred to an ice bath to terminate the reaction. Four millilitres of toluene was added to the contents of the tubes and mixed thoroughly using a cyclomixer (CM101, REMI India) for $15 \mathrm{sec}$. Chromophore containing toluene was aspirated from the aqueous phase. Then the absorbance was measured in a UV-spectrophotometer at $520 \mathrm{~nm}$ against toluene. Proline was measured from the standard curve prepared with authentic proline and its amount was calculated on dry weight basis.

\subsection{Estimation of Ascorbic Acid (AsA) and Non-Protein Thiol Compounds (NP-SHs)}

The measurement of total AsA and NP-SH groups were carried out as described in Cakmak and Marschner [36]. Five hundred milligrams of fresh leaf samples were extracted with $5 \mathrm{ml}$ of $5 \%$ meta-phosphoric acid, and centrifuged at $15,000 \times \mathrm{g}$ for $15 \mathrm{~min}$. For the assay of AsA, the reaction mixture contained $0.2 \mathrm{ml}$ aliquot, $0.5 \mathrm{ml}$ $150 \mathrm{mM}$ phosphate buffer (pH 7.4) containing $5 \mathrm{mM}$ EDTA, $0.1 \mathrm{ml} 10 \mathrm{mM}$ DTT and $0.1 \mathrm{ml} 0.5 \%(\mathrm{w} / \mathrm{v})$ $N$-ethylmaleimide (NEM) to remove excess DTT. To this, $0.4 \mathrm{ml} 10 \%$ trichloroacetic acid (TCA), $0.4 \mathrm{ml} 44 \%$ ortho-phosphoric acid, $0.4 \mathrm{ml} 2.1$ 'bipyridine in $70 \%$ ethanol and $0.2 \mathrm{ml} 3 \% \mathrm{FeCl}_{3}$ were added to develop colour. The mixtures were then incubated in a water bath at $40^{\circ} \mathrm{C}$ for $40 \mathrm{~min}$ and the colour produced was read at 525 $\mathrm{nm}$. AsA was used as a standard and the concentration of AsA in the samples was calculated and expressed in $\mu \mathrm{mol} \cdot \mathrm{g}^{-1}$ dry weight.

For the assay of $-\mathrm{SH}$ groups, the reaction mixture contained $0.5 \mathrm{ml}$ aliquot of the supernatant, $2.5 \mathrm{ml}$ of 150 $\mathrm{mM}$ phosphate buffer (pH 7.4) containing $5 \mathrm{mM}$ EDTA and $0.5 \mathrm{ml} 6 \mathrm{mM}$ 5-5'-dithiobis-(2-nitro-benzoic acid). Following incubation at room temperature, the colour produced was measured at $412 \mathrm{~nm}$ with a spectrophotometer. Reduced glutathione (GSH) was used as a standard. The concentration of NP-SH compounds in the samples were calculated and expressed in $\mu \mathrm{mol} \cdot \mathrm{g}^{-1} \mathrm{dry}$ weight.

\subsection{Antioxidant Enzyme Assays and In-Gel Enzyme Activity Staining}

Fresh leaf tissue was homogenized in $50 \mathrm{mM}$ Tris- $\mathrm{HCl}$ (pH 7.5) buffer containing $40 \mathrm{mM}$ phenyl methyl sulfonyl fluoride (PMSF), and 2\% (w/v) polyvinyl poly pyrrolidone (PVPP) with the addition of $2 \mathrm{mM}$ AsA for the APX assay. The extract was centrifuged at $15,000 \times \mathrm{g}$ for $20 \mathrm{~min}$ at $4^{\circ} \mathrm{C}$ and the resultant supernatant was used for all the enzyme assays. The amount of protein was calculated according to Lowry et al. [37].

All enzymic activities were measured spectrophotometrically at $25^{\circ} \mathrm{C}$. Superoxide dismutase (SOD) activity was assayed using the method described by Urbanek et al. [38]. One unit of SOD activity was defined as the amount of enzyme required to cause 50\% inhibition of the NBT photoreduction rate. Guaiacol peroxidase (GPX) activity was determined in terms of oxidation of guaiacol by $\mathrm{H}_{2} \mathrm{O}_{2}$ [39], as measured by the increase in absorbance at $420 \mathrm{~nm}\left(\mathrm{E}=26.6 \mathrm{mM}^{-1} \cdot \mathrm{cm}^{-1}\right)$. Ascorbate peroxidase (APX) activity was determined as described by the method of Nakano and Asada [13]. The oxidation of AsA in the reaction mixture was measured using the rate of decrease in absorbance at $290 \mathrm{~nm}$ and was calculated using an extinction coefficient of $2.8 \mathrm{mM}^{-1} \cdot \mathrm{cm}^{-1}$.

Glutathione reductase (GR) activity was assayed as per the method of Foster and Hess [40], the activity was measured at $340 \mathrm{~nm}$ and calculated using the extinction coefficient for NADPH of $6.22 \mathrm{mM}^{-1} \cdot \mathrm{cm}^{-1}$ and expressed as $\mu$ mol NADPH oxidized per gram fresh weight. Glutathione S-transferase was assessed by the method 
of Habig et al. [41], the enzyme was assayed by its ability to conjugate GSH and CDNB, the extent of conjugation caused a proportionate change in the absorbance at $340 \mathrm{~nm}$. GST activity was calculated using the extinction co-efficient of the product formed $\left(9.6 \mathrm{mM}^{-1} \cdot \mathrm{cm}^{-1}\right)$ and was expressed as nmol. GSH oxidized $/ \mathrm{h}^{-1} / \mathrm{g}^{-1} \mathrm{DW}$.

Poly acrylamide gel electrophoresis (PAGE) was performed on $1.5 \mathrm{~mm}$ thick gels on the mini slab gel electrophoresis apparatus (Hoefer, USA) according to Laemmli [42], except the addition of SDS, and the gels were captured in a gel documentation system (UvItec, UK). SOD isoforms were visualized following the method described by Beauchamp and Fridovich [43]. Activity of GPX isoforms was visualized on 7.5\% gel according to staining procedure of Birecka [44]. In-gel APX activity staining was performed according to Lee and Lee [45]. GR isoforms were visualized following the method described by Ye et al. [46].

\subsection{Estimation of $\mathrm{Pb}$ Content}

Oven dried powder sample $(0.5 \mathrm{~g})$ of roots and leaves was taken in a $50 \mathrm{ml}$ boiling test tube and $5 \mathrm{ml}$ of concentrated nitric acid (70\%) was added and incubated at RT overnight. The next day, $5 \mathrm{ml}$ of di-acid mixture $\left(\mathrm{HNO}_{3}: \mathrm{H}_{2} \mathrm{O}_{2}: 10: 4\right)$ was added to it and placed on a mantle (REMI, India) till all the white fumes evaporated and the thick white residue was left out in flask. These diluted samples were used for $\mathrm{Pb}$ estimation using ICP-OES (Inductively Coupled Plasma-Optical Emission Spectrophotometer, Optima 8000, Perkin Elmer India). The concentration of $\mathrm{Pb}$ was expressed as $\mu \mathrm{g} \cdot \mathrm{per} \cdot \mathrm{g}^{-1}$ dry weight.

\subsection{Statistical Analysis}

All data were analyzed using the SPSS (Statistical Package for the Social Sciences) version 16.0. Data presented here are mean values and standard deviation $( \pm \mathrm{SD})$. One-way ANOVA was carried out using Post hoc multiple comparison from the Duncan's test at a significance level of $\mathrm{p}<0.05$.

\section{Results}

The two groundnut cultivars differed from each other in terms of morphological, physiological and antioxidative responses to $\mathrm{Pb}$-stress.

\subsection{Effect of Pb on Plant Growth}

Effect of different concentration of $\mathrm{Pb}$ on the growth of both groundnut cultivars in terms of shoot and root length was measured (Figure 1(a)). In general, both cultivars showed reduced growth under Pb-stress compared to unstressed conditions. Growth of cultivar $\mathrm{K} 6$ was less affected due to $\mathrm{Pb}$ treatments compared with cultivar K9. After exposure to $800 \mathrm{ppm} \mathrm{Pb}$, the reduction in the root growth was $24 \%$ and $46 \%$ in cultivar K6 and K9 respectively, compared to their respective controls. Whereas the shoot growth of both cultivars remained less affected than root growth and the percent reduction was 14\% in cultivar K6 compared to 38\% in cultivar K9 (Figure 1(a)).

\subsection{Effect of $\mathrm{Pb}$ on Plant Drymass}

Increased $\mathrm{Pb}$ metal concentration significantly reduced the biomass of two groundnut cultivars. $\mathrm{Pb}$ induced root and shoot biomass reduction in cultivar K6 was lower than that of cultivar K9. At $800 \mathrm{ppm} \mathrm{Pb}$ treatments the reduction in root dry mass was 13\% in cultivar K6 compared to 30\% in cultivar $\mathrm{K} 9$ and when compared to their controls (Figure 1(b)). Similarly, the reduction in shoot dry mass was 18\% in cultivar K6 and 47\% in cultivar K9.

\subsection{Histochemical Detection of Leaves for $\mathrm{O}_{2}{ }^{\circ}$ and $\mathrm{H}_{2} \mathrm{O}_{2}$}

Histochemical staining was employed to bring out in situ accumulation of $\mathrm{O}_{2}{ }^{\bullet-}$ and $\mathrm{H}_{2} \mathrm{O}_{2}$, two important reactive oxygen species. Under control conditions there was no detectable difference between cultivar $\mathrm{K} 6$ and $\mathrm{K} 9$ in the accumulation of $\mathrm{O}_{2}{ }^{--}$and $\mathrm{H}_{2} \mathrm{O}_{2}$ radicals. Figure 2 illustrates that there was an increase of $\mathrm{O}_{2}{ }^{\bullet-}$ and $\mathrm{H}_{2} \mathrm{O}_{2}$ levels in both cultivars exposed to higher $\mathrm{Pb}$ concentrations compared with their controls. However, remarkable differences were observed between the cultivars with the increasing $\mathrm{Pb}$ treatment, in which cultivar $\mathrm{K} 9$ showed more local blue spots (Figure 2(c), indicator of $\mathrm{O}_{2}{ }^{\bullet-}$ ) and brown spots (Figure 2(d), indicator of $\mathrm{H}_{2} \mathrm{O}_{2}$ ) than 

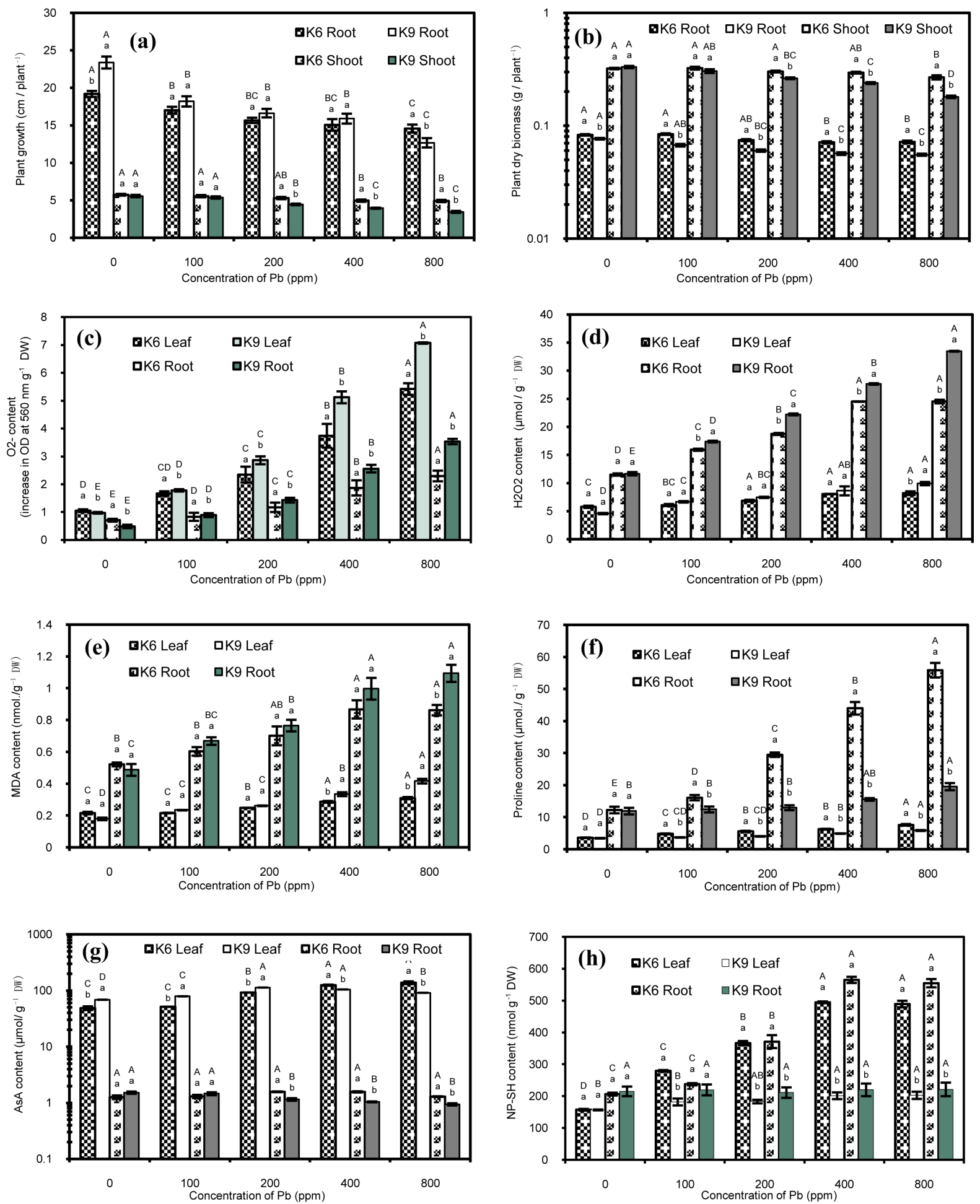

Figure 1. Effect of increasing concentrations of $\mathrm{Pb}\left(\mathrm{NO}_{3}\right)_{2}$ on (a) plant growth (cm·plant $\left.{ }^{-1}\right)$, (b) plant biomass (g.plant $\left.{ }^{-1}\right)$; (c) superoxide anion production (increase in OD at $\left.590 \mathrm{~nm} \mathrm{~h} \mathrm{~g}{ }^{-1} \mathrm{DW}\right)$; (d) hydrogen peroxide production $\left(\mu \mathrm{mol} \cdot \mathrm{g}^{-1} \mathrm{DW}\right)$; (e) malondialdehyde (MDA) content $\left(\mu \mathrm{mol} \cdot \mathrm{g}^{-1} \mathrm{DW}\right)$; (f) free praline content $\left(\mu \mathrm{mol} \cdot \mathrm{g}^{-1} \mathrm{DW}\right)$; $(\mathrm{g})$ ascorbic acid content $\left(\mu \mathrm{mol} \cdot \mathrm{g}^{-1} \mathrm{DW}\right)$ and $(\mathrm{h})$ non-protein thiol content $\left(\mu \mathrm{mol} \cdot \mathrm{g}^{-1} \mathrm{DW}\right)$ of two groundnut cultivars. Error bars indicate SD $(n=5)$. Different uppercase letters indicate significant differences between cultivars in response to treatments (Student's t test; JMP 8.0 software), and lowercase letters indicate significant differences within the cultivar in response to treatments (TukeyKramer HSD test; JMP 8.0 software). 


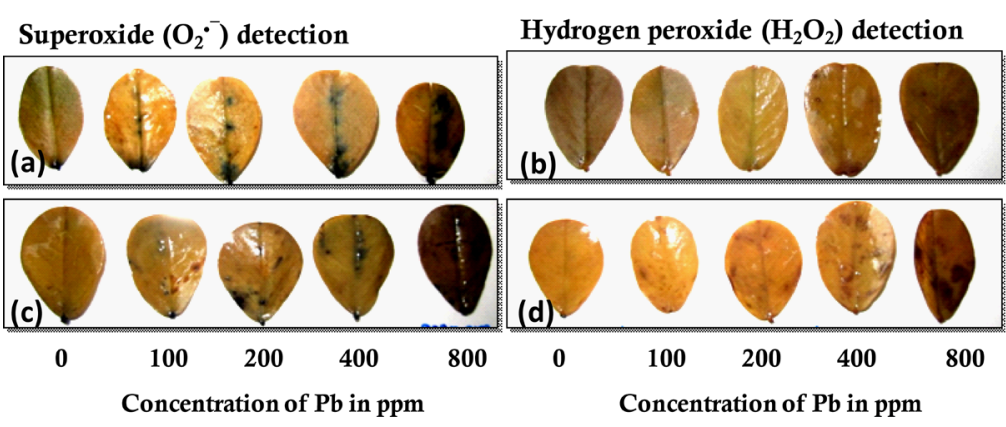

Figure 2. Effect of increasing concentration of $\mathrm{Pb}\left(\mathrm{NO}_{3}\right)_{2}$ on free radical generation in cultivar K6 (a) (b) and cultivar K9 (c) (d) leaves.

cultivar K6 (Figure 2(a), (b)).

\subsection{Effect of $\mathrm{Pb}$ on $\mathrm{O}_{2}{ }^{-}$- and $\mathrm{H}_{2} \mathrm{O}_{2}$ Production}

$\mathrm{Pb}$ treatment caused a significant increase in $\mathrm{O}_{2}{ }^{--}$production in both groundnut cultivars compared to their controls. A linear increase in $\mathrm{O}_{2}{ }^{\bullet-}$ accumulation with increasing concentration of $\mathrm{Pb}$ was observed in both cultivars. However, a more pronounced increase was observed in the leaves of cultivar K9 compared to cultivar K6. At $800 \mathrm{ppm} \mathrm{Pb}$, the per cent increase in the $\mathrm{O}_{2}{ }^{-{ }^{-}}$production was $624 \%$ in cultivar $\mathrm{K} 9$ and $415 \%$ in cultivar K6 respectively, compared to their respective controls (Figure $1(\mathrm{c})$ ). Whereas, the production of $\mathrm{H}_{2} \mathrm{O}_{2}$ was $42 \%$ in cultivar K6 compared to $117 \%$ in cultivar K9 (Figure 1(d)).

\subsection{Lipid Peroxidation (MDA Content)}

Malondialdehyde content (Figure 1(e)) in roots and leaves of both groundnut cultivars was elevated due to $\mathrm{Pb}$ toxicity and the magnitude of elevation was concentration dependent in both the cultivars. However, the per cent increase in MDA content was relatively less in cultivar K6 than in K9. The root MDA content was increased more than leaf MDA content in both the cultivars under Pb-stress conditions.

\subsection{Free Proline Content}

There was a linear increase in free proline accumulation with increasing $\mathrm{Pb}$ concentration was observed in groundnut cultivars. However, a more pronounced increase was noticed in the cultivar K6 compared to cultivar K9. After expose to 800 ppm Pb, the percent increase was 104\% in cultivar K6 and 70\% in cultivar K9 with respective to their controls (Figure $1(\mathrm{f})$ ).

\subsection{Effect of $\mathrm{Pb}$ on Ascorbic Acid (AsA) and Malondialdehyde (MDA) Content}

Significant changes in the AsA content between two groundnut cultivars due to $\mathrm{Pb}$ treatments were observed. Cultivar K9 showed higher AsA content at $200 \mathrm{ppm} \mathrm{Pb}$ when compared to 400 and $800 \mathrm{ppm} \mathrm{Pb}$ treatments (Figure 1(g)). Whereas, cultivar K6 showed gradual increase in the AsA content with increasing Pb concentration. Nevertheless, the per cent increase in AsA content was more in cultivar K6 than K9 due to Pb treatments.

\subsection{Effect of Pb on Non-Protein Thiols Content (NP-SH)}

The concentration of NP-SH in leaves and root of cultivar K6 steadily and consistently increased with increasing $\mathrm{Pb}$-stress when compared to controls. In contrast, levels of NP-SH contents were remained unchanged due to $\mathrm{Pb}$ treatment in leaves and roots of cultivar K9 (Figure 1(h)).

\subsection{Effect of Pb on Antioxidant Enzyme Activities}

Pb-stress caused a significant increase in the total SOD enzyme activity in cultivar K6. The total SOD enzyme activity was increased due to Pb-stress up to 400 ppm, but decreased at $800 \mathrm{ppm}$ Pb-stress (Figure 3(a)). Similarly, SOD activity was increased in cultivar K9 up to $400 \mathrm{ppm} \mathrm{Pb}$ but decreased at $800 \mathrm{ppm} \mathrm{Pb}$ concentration. 

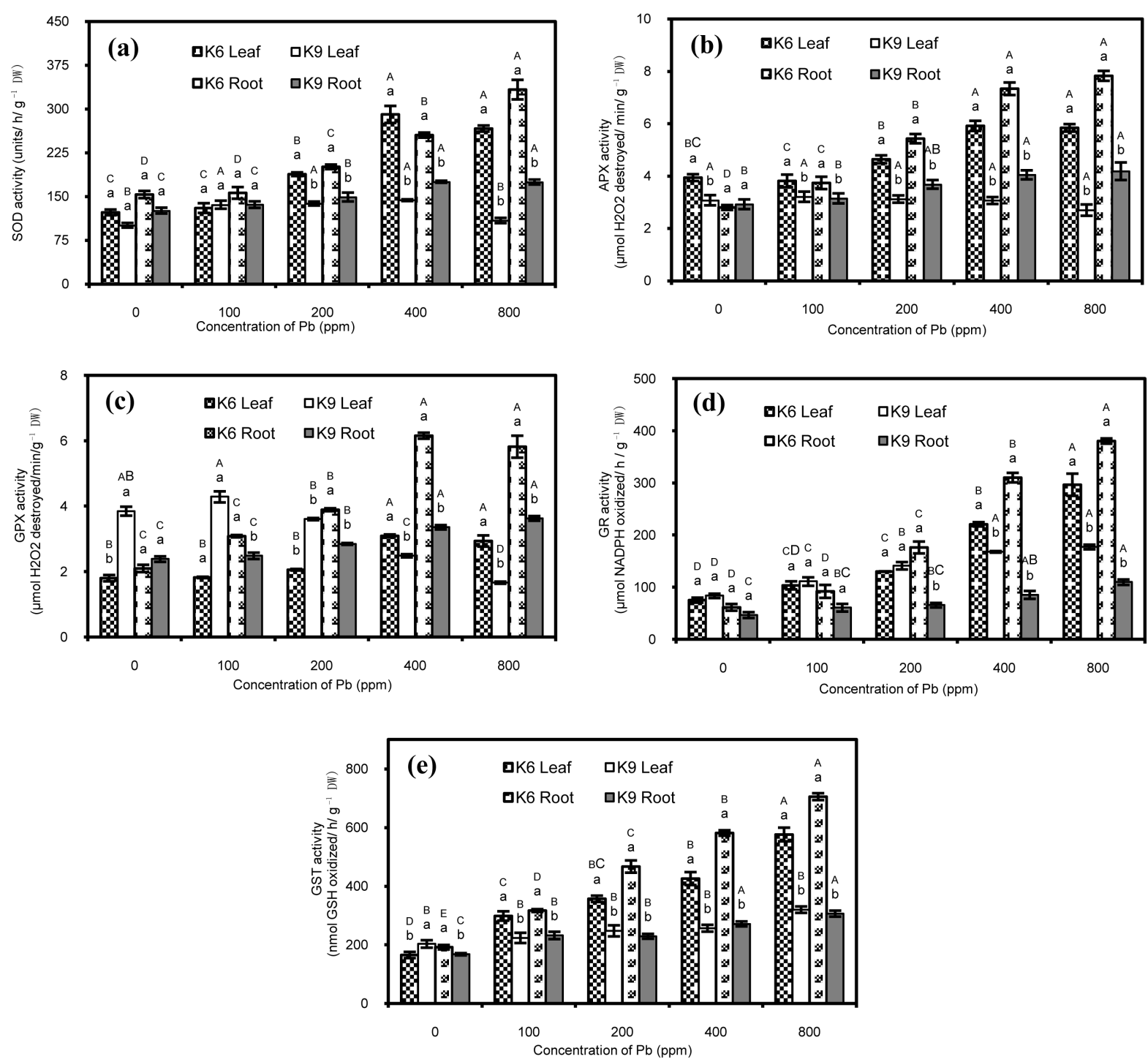

Figure 3. Effect of increasing concentrations of $\mathrm{Pb}\left(\mathrm{NO}_{3}\right)_{2}$ on (a) superoxide dismutase (SOD) activity (units h. $\left.\mathrm{g}^{-1} \mathrm{DW}\right)$; (b) ascorbate peroxidase (APX) activity $\left(\mu \mathrm{mol} \mathrm{H}_{2} \mathrm{O}_{2}\right.$ reduced min $\left.\cdot \mathrm{g}^{-1} \mathrm{DW}\right)$; (c) guaiacol peroxidase (GPX) activity $\left(\mu \mathrm{mol} \mathrm{H}_{2} \mathrm{O}_{2}\right.$

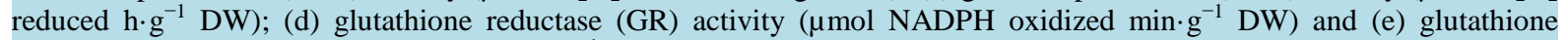

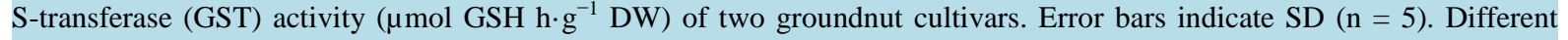
uppercase letters indicate significant differences between cultivars in response to treatments (Student's t test; JMP 8.0 software), and lowercase letters indicate significant differences within the cultivar in response to treatments (Tukey-Kramer HSD test; JMP 8.0 software).

However, in both cultivars the activity was remained higher in Pb-stressed plants compared to those controls. The percent increase in SOD enzyme activity was more in cultivar K6 than in cultivar K9.

Marked differences in APX activity were found between two cultivars after 10 days of $\mathrm{Pb}$ treatments (Figure 3(b)). Leaf APX activity in cultivar K9 was unaffected under Pb-stress but root APX activity was increased at higher $\mathrm{Pb}$ concentration (400 - $800 \mathrm{ppm}$ ) when compared to respective controls. In cultivar K6 the leaf and root APX activities were increased with increasing Pb-stress when compared to controls.

$\mathrm{Pb}$-stress caused differential response in GPX activity in two groundnut cultivars (Figure 3(c)). GPX activity was significantly increased in leaves and roots cultivar K6 and peaked maximum activity at $400 \mathrm{ppm}$ of $\mathrm{Pb}$-stress. The GPX activity was significantly decreased in leaves and increased in roots of cultivar $\mathrm{K} 9$ at higher $\mathrm{Pb}$ concentration.

The activities of glutathione reductase (GR, Figure 3(d)) and glutathione S-transferase (GST, Figure 3(e)) 
increased in Pb-stressed plants of cultivar K6 and cultivar K9. However the per cent increase was relatively more in cultivar K6 than in cultivar K9 under Pb-tress conditions. And, the degree of elevation in the activities of GR and GST was more in roots compared to leaves of Pb-stressed plants of both the cultivars.

$\mathrm{Pb}$-induced oxidative stress was further corroborated by the antioxidant isozyme profiling by native-PAGE (Figure 4). At least six SOD (Figure 4(a)), four APX (Figure 4(b)) and five GPX (Figure 4(c)) isozymes were visualized on in-gel enzyme activity staining. The staining intensities of these isozymes were differed between unstressed and $\mathrm{Pb}$-stressed conditions in both cultivars. An enhanced isozymic activity staining was observed for all three enzymes in Pb-stressed plants compared to unstressed plants. The increased SOD, APX and GPX activities were relatively greater in cultivar K6 compared to cultivar K9.

\subsection{Pb Accumulation}

The $\mathrm{Pb}$ concentration (Table 1) of roots and leaves in two groundnut cultivars were increased under Pb-stress when compared to controls. The magnitude of increase in the $\mathrm{Pb}$ content of both the cultivars was found to be dependent on soil $\mathrm{Pb}$ concentration. Furthermore, the $\mathrm{Pb}$ content was relatively more in roots than in leaves. At $800 \mathrm{ppm}$ of $\mathrm{Pb}$, there was a 4.5-fold increase in leaves and 30-fold increase in $\mathrm{Pb}$ content in roots of cultivar K6, whereas, 18-fold and 55-fold increase in leaves and roots of cultivar K9, respectively when compared to corresponding controls.
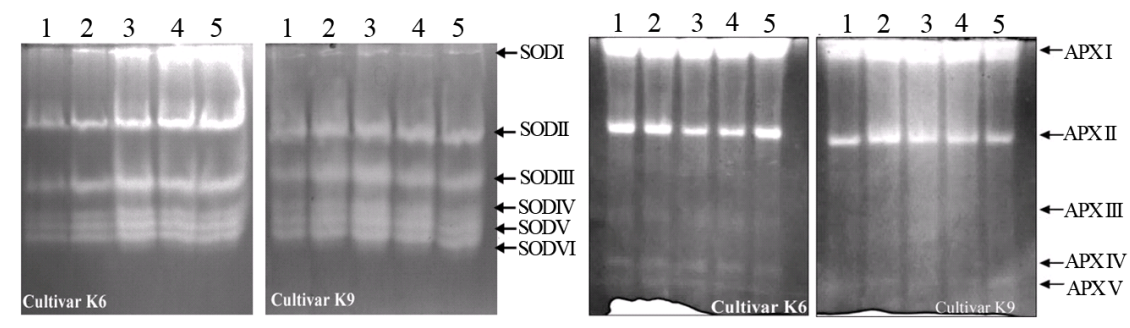

(a)

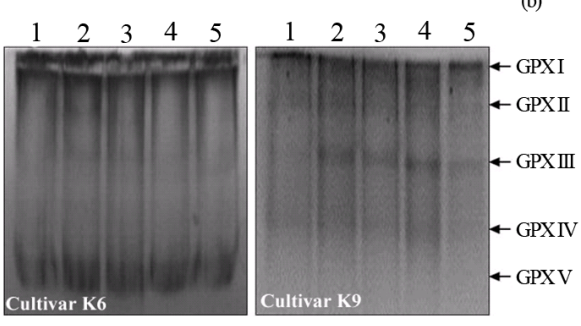

(c)

Figure 4. Native gel stained for the activity of (a) SOD; (b) APX and (c) GPX of groundnut (cultivar K6 and K9) leaves. Equal amount of protein $(200 \mu \mathrm{g})$ was loaded on the gel. Lane $1-$ control; lane 2-100 ppm; lane 3-200 ppm; lane 4-400 ppm; lane 5 $-800 \mathrm{ppm} \mathrm{Pb}\left(\mathrm{NO}_{3}\right)_{2}$.

Table 1. $\mathrm{Pb}$ content $\left(\mathrm{mg} \cdot \mathrm{g}^{-1} \mathrm{DW}\right.$ in roots and ug $\cdot \mathrm{g}^{-1} \mathrm{DW}$ in leavews) of control and $\mathrm{Pb}$-stressed groundnut cultivars $( \pm \mathrm{SD})$.

\begin{tabular}{|c|c|c|c|c|c|c|c|c|c|c|}
\hline \multirow{2}{*}{ Organ } & \multicolumn{5}{|c|}{ Cultivar K6 } & \multicolumn{5}{|c|}{ Cultivar K9 } \\
\hline & 0 & 100 & 200 & 400 & 800 & 0 & 100 & 200 & 400 & 800 \\
\hline Leaf & $\begin{array}{c}0.199 \mathrm{c} \\
\pm 0.009 \\
(100)\end{array}$ & $\begin{array}{c}0.561 \mathrm{~b} \\
\pm 0.16 \\
(261.5)\end{array}$ & $\begin{array}{c}2.74 \mathrm{a} \\
\pm 0.046 \\
(284.6)\end{array}$ & $\begin{array}{c}3706 \mathrm{a} \\
\pm 0.302 \\
(407.7)\end{array}$ & $\begin{array}{l}6.106 \mathrm{a} \\
\pm 0.166 \\
(469.2)\end{array}$ & $\begin{array}{c}0.693 \mathrm{~d} \\
\pm 0.046 \\
(100)\end{array}$ & $\begin{array}{c}3.46 \mathrm{c} \\
\pm 0.122 \\
(346.1)\end{array}$ & $\begin{array}{c}8.05 \mathrm{~b} \\
\pm 0.122 \\
(776.9)\end{array}$ & $\begin{array}{l}17.33 \mathrm{~b} \\
\pm 0.092 \\
(1149)\end{array}$ & $\begin{array}{c}38.1 \mathrm{a} \\
\pm 0.323 \\
(1800)\end{array}$ \\
\hline Root & $\begin{array}{c}0.13 c \\
\pm 0.046 \\
(100)\end{array}$ & $\begin{array}{c}0.34 \mathrm{c} \\
\pm 0.046 \\
(281.4)\end{array}$ & $\begin{array}{c}0.37 \mathrm{~b} \\
\pm 0.046 \\
(1376.8)\end{array}$ & $\begin{array}{c}0.53 \mathrm{~b} \\
\pm 0.046 \\
(1862.3)\end{array}$ & $\begin{array}{c}0.61 \mathrm{a} \\
\pm 0.046 \\
(3068.3)\end{array}$ & $\begin{array}{c}0.13 e \\
\pm 0.046 \\
(100)\end{array}$ & $\begin{array}{c}0.45 \mathrm{~d} \\
\pm 0.092 \\
(499.27)\end{array}$ & $\begin{array}{c}1.01 \mathrm{c} \\
\pm 0.092 \\
(1161.6)\end{array}$ & $\begin{array}{c}1.49 \mathrm{~b} \\
\pm 0.046 \\
(2500.7)\end{array}$ & $\begin{array}{c}2.34 \mathrm{a} \\
\pm 0.092 \\
(5497.8)\end{array}$ \\
\hline
\end{tabular}

The mean values $(n=5)$ in a row followed by different letter for each cultivar are significantly different $(P \leq 0.05)$ according to Duncan's multiple range (DMR) test. Figures in parenthesis represent per cent of control. 


\section{Discussion}

Morphological changes such as root and shoot growth in response to Pb-stress has been studied by several investigators. It has been reported that root and shoot growth was reduced in plants [23] [27] [47], by Pb-stress. The growth of legume plants grown on $\mathrm{Pb}$ ore tailings was reported to be drastically affected [28]. Pb also inhibited root and shoot growth in tobacco [48], and wheat [7]. Similarly, in the present study, the root and shoot growth of cultivar K6 and cultivar K9 were inhibited by Pb-stress and the reduction was found to be concentration dependent. However, the per cent decrease in root and shoot growth was less in cultivar K6 than in cultivar $\mathrm{K} 9$, which indicates the better adaptation of former one to Pb-stress. The reduction in root length and shoot length under $\mathrm{Pb}$-stress may be due to the inhibition in cell elongation process [49], or due to reduced mitotic activity as observed in lupin roots [50].

Generally, excess concentration of heavy metals in soil results in lowering plant biomass production. Biomass production has been considered as an index of tolerance level of plants growing on metal enriched soils. Cox and Hutchinson [51], have reported that the dry mass production in non-tolerant plant was significantly negatively correlated with log metal concentration in soil, but the same relationship with tolerant plant was positive. Similarly, in the present study, the dry mass accumulation was much less affected in tolerant cultivar K6 than susceptible cultivar K9 with increasing stress intensity. In concomitant to this, Ekmekci et al. [23], reported that the shoot and root ratio (dry mass) was affected by increasing $\mathrm{Pb}$ concentrations in maize. Inhibition of fresh and dry mass accumulation under Pb-stress conditions was also reported in cotton seedlings [52], and in sunflower [53]. An increase in the metal supply resulted in inhibition of leaf area in the cotton [52], garden cress [3], and tomato [47] [54]. In contrast, in the present study Pb-stress caused no significant inhibition in the leaf area in tolerant cultivar K6 which reveals it tolerant nature to $\mathrm{Pb}$-stress.

Proline continues to be the most studied molecule under abiotic stresses in plants. A pronounced increase in proline content has been noticed in Solanum nigrum [55], and wheat [5], when the plants were exposed to heavy metals. Similarly, in the present study, the proline content was increased in leaves and roots of both cultivars with increasing concentration of $\mathrm{Pb}$. Further, accumulation of proline is more pronounced in root than in leaves of both cultivars. However, the proline accumulation was greater in cultivar K6 than in cultivar K9. It has been reported previously that proline accumulation in stress tolerant plants is higher than in stress sensitive plants [56]. AsA is the major primary antioxidant in all sub-cellular compartments, which reacts directly with ROS, and also acts as a secondary antioxidant by reducing the oxidized form of $\alpha$-tocopherol and preventing membrane damage [57]. In this study, the AsA content was significantly higher (Figure 2(d)) in cultivar K6 than in cultivar K9 in response to Pb-stress. These results suggest that the higher level of AsA in cultivar K6 could be the reason for its relative tolerance to $\mathrm{Pb}$-stress than cultivar K9. Similar results have been reported by $\mathrm{Li}$ et al. [58] in two cultivars of Brassica species grown under copper stress.

$\mathrm{H}_{2} \mathrm{O}_{2}$ and $\mathrm{O}_{2}{ }^{--}$are two kinds of reactive oxygen species causing oxidative stress in plants. Increased reactive oxygen species have been detected in the roots of maize and soybean [59], and in leaves of Vallisneria natans [60], Alocasia macrorrhiza [61] under heavy metal stress. In this study, we further confirmed that $\mathrm{Pb}$ induced generation of $\mathrm{H}_{2} \mathrm{O}_{2}$ and $\mathrm{O}_{2}{ }^{--}$in vivo in leaves by histochemical staining. Through the Haber-Weiss reaction $\mathrm{H}_{2} \mathrm{O}_{2}$ and $\mathrm{O}_{2}{ }^{\bullet-}$ can be transformed to the highly reactive oxidant $\mathrm{OH}^{\bullet-}$, which causes lipid peroxidation in plant cell [62]. MDA is a cytotoxic product of lipid peroxidation and an indicator of membrane damage from oxidative stress. $\mathrm{Pb}$ toxicity is reported to induce the increase of MDA in Talinum triangulare [63]. As excess of heavy metals stimulate the formation of free radicals [64]. A constitutive amount of $\mathrm{O}_{2}{ }^{\boldsymbol{C}^{-}}$is considered as a signal molecule in signal transduction and programmed cell death [65], however, if $\mathrm{O}_{2}{ }^{\bullet-}$ not scavenged efficiently, excessive accumulation of $\mathrm{O}_{2}{ }^{\bullet-}$ might impair biological molecules. SOD can catalyze the dismutation reaction of $\mathrm{O}_{2}{ }^{\bullet-}$ into molecular oxygen and $\mathrm{H}_{2} \mathrm{O}_{2}$, and thus represent primary antioxidant defence in the plant cells. The level of $\mathrm{O}_{2}{ }^{\bullet-}$ and $\mathrm{H}_{2} \mathrm{O}_{2}$ were increased significantly, in the leaves and roots of both groundnut cultivars in all $\mathrm{Pb}$ treatments were observed.

Plant possess a well organized ROS scavenging systems comprising enzymatic such as SOD, APX, GR, GPX and CAT, and non-enzymatic antioxidants such as AsA, GSH, NP-SH and PCs. A coordinated function of these systems plays an important role in scavenging ROS and maintaining redox status of the cell [66]. In the current study, the ROS levels in groundnut are controlled by a complex enzymatic and non-antioxidant system. The present results show an increase of AsA and NP-SH coupled with enhanced SOD, GPX and APX activities in groundnut cultivars growing in the presence of $\mathrm{Pb}$-stress could be attributed to the increased $\mathrm{O}_{2}{ }^{--}$and $\mathrm{H}_{2} \mathrm{O}_{2}$ 
radical concentration. Increased activity of APX may efficiently scavenge $\mathrm{H}_{2} \mathrm{O}_{2}$ to protect against oxidative damage, SOD, APX and GPX, in general, show simultaneous induction and decline, which may be due to their co-regulation as reported earlier [67].

Further, the variations in isozyme profiles and increase in the isozyme activities are considered to play important role in the cellular defence against stress induced oxidative stress. The intensity of the isozyme bands can reflect relative quantity and activity of the isozyme [68]. Pattern of SOD, GPX and APX isozyme expression obtained from leaf tissue of both the cultivars are shown in Figure 4. Although we did not identify the specific activity of each isozyme, the total antioxidant isozymes in different tissues might be connected with increased requirement to combat $\mathrm{Pb}$ toxicity. In the present study, the involvement of free radicals in membrane lipid peroxidation in both the cultivars subjected to $\mathrm{Pb}$-stress could be a possible reason for the increase in MDA content. Generally, free radical generation and membrane damage would be low in tolerant plants and thereby the formation of lower levels of MDA content.

The reduced form of glutathione (GSH) is one of the most important components of metabolism of NP-SH and play important roles in heavy metal tolerance and sequestration [69] [70]. GSH is the direct precursor of phytochelatins (PCs) in a reaction catalyzed by phytochelatin synthase (PCS). It is known that the metal stress alleviates the depletion of GSH [60], and enhance PCs synthesis, resulting in an increased metal tolerance of plants [71]-[73]. Nouairi et al. [71], reported that the level of PC-SH in tolerant plants was significantly increased under Cd stress in Brassica juncea. Similarly, in the present investigation, thiol (-SH) compounds were significantly higher in cultivar $\mathrm{K} 6$ under $\mathrm{Pb}$-stress compared to cultivar K9. This may be ascribed to increased levels of PCs content in tolerant cultivar K6.

$\mathrm{Pb}$ uptake studies in plants have demonstrated that roots have an ability to take up significant quantities of $\mathrm{Pb}$ simultaneously, greatly restricting its translocation to the above ground parts [49]. In this study, both groundnut cultivars have the ability to accumulate $\mathrm{Pb}$ primarily in their roots and transport it to their leaves in much lesser concentration. Similar results were reported by [6] and [23]. The results also indicated that the accumulated $\mathrm{Pb}$ in roots of cultivar K9 was higher than the roots of cultivar K6 in all Pb treatments. Based on comparative studies of metal content in plant parts Baker and Walker [74], suggested that uptake, translocation and accumulation mechanisms differed for various heavy metals and for the species. It is known that the root system partially defends the above ground parts from $\mathrm{Pb}$ [75], as shown in the present study. Generally, the plants with highest tolerance take-up the smallest ratio of the total soil-metal and had the lowest shoot metal contents [6] [28]. In parallel to this, although both the cultivars in this study accumulated low Pb levels in the leaves, cultivar K6 accumulated still a less proportion of $\mathrm{Pb}$ by restricting the uptake and further translocation from roots to leaves. Our study also indicated that the uptake and translocation properties of $\mathrm{Pb}$ indicated the retaining abilities of the roots to $\mathrm{Pb}$.

\section{Conclusion}

In conclusion, the two groundnut cultivars showed differential tolerance to Pb-stress. The higher tolerance of cultivar $\mathrm{K} 6$ to $\mathrm{Pb}$-stress was due to the lower levels of $\mathrm{Pb}$ accumulation in the leaf and root tissues and coordinative interaction between the non-enzymatic and enzymatic antioxidants systems, which serves efficiently to protect cultivar K6 from the oxidative stress and thus the relatively better growth than the susceptible cultivar K9. Overall, antioxidant machinery plays an important role in Pb-stress tolerance of plants. In the present study, we hypothesized that: enhanced levels of non-enzymatic antioxidants and MDA content in both groundnut cultivars differ in sensitivity to $\mathrm{Pb}$ exposure, to activate the multi tolerance mechanism of antioxidative enzymes under $\mathrm{Pb}$-stress, to induce genotoxic changes caused by $\mathrm{Pb}$-stress, potential detoxification strategies are evolved. The results of the present study also demonstrate the effect of $\mathrm{Pb}$ exposure in cultivar K6, the cultivar capability to activate multi defense mechanism against oxidative damage and genotoxicity caused by $\mathrm{Pb}$ ions may be a key factor in the detoxification mechanism of plant tolerance to unfavourable conditions.

\section{Acknowledgements}

We acknowledge the DST (SR/SO/PS/001/2011 and CSIR-(38/1305/11/EMR-II), GoI, New Delhi for financial assistance in the form of research grants to CS. We thank the DST-PURSE facility, Sri Venkateswara University, Tirupati for ICP-OES analysis. 


\section{References}

[1] Malar, S., Vikram, S.S., Favas, P.J.C. and Perumal, V. (2014) Lead Heavy Metal Toxicity Induced Changes on Growth and Antioxidative Enzymes Level in Water Hyacinths [Eichhornia crassipes (Mart.)]. Botanical Studies, 55, 1-11. http://dx.doi.org/10.1186/s40529-014-0054-6

[2] Puschenreiter, M., Schnepf, A., Molina-Millan, I., Fitz, W.J., Horak, O., Klepp, J., Schrefl, T., Lombi, E. and Wenzel, W.W. (2005) Changes of Ni Biogeochemistry in the Rhizosphere of the Hyperaccumulator Thlaspi goesingense. Plant and Soil, 271, 205-218. http://dx.doi.org/10.1007/s11104-004-2387-5

[3] Nagajyoti, P.C., Lee, K.D. and Sreekanth, T.V.M. (2010) Heavy Metals, Occurrence and Toxicity for Plants: A Review. Environmental Chemistry Letters, 8, 199-216. http://dx.doi.org/10.1007/s10311-010-0297-8

[4] Gill, S.S., Khan, N.A. and Tuteja, N. (2012) Cadmium at High Dose Perturbs Growth, Photosynthesis and Nitrogen Metabolism While at Low Dose It up Regulates Sulfur Assimilation and Antioxidant Machinery in Garden Cress (Lepidium sativum L.). Plant Science, 182, 112-120. http://dx.doi.org/10.1016/j.plantsci.2011.04.018

[5] Lamhamdi, M., Bakrim, A., Aarab, A., Lafont, R. and Sayah, F. (2011) Lead Phytotoxicity on Wheat (Triticum aestivum L.) Seed Germination and Seedlings Growth. Comptes Rendus Biologies, 334, 118-126. http://dx.doi.org/10.1016/j.crvi.2010.12.006

[6] Reddy, A.M., Kumar, S.G., Jyothsnakumar, G., Thimmanaik, S. and Sudhakar, C (2005) Lead Induced Changes in Antioxidant Metabolism of Horsegram (Macrotyloma uniflorum (Lam.) Verdc.) and Bengalgram (Cicer arietinum L.). Chemosphere, 60, 97-104. http://dx.doi.org/10.1016/j.chemosphere.2004.11.092

[7] Yang, Y., Wei, X., Lu, J., You, J., Wang, W. and Shi, R. (2010) Lead-Induced Phytotoxicity Mechanism Involved in Seed Germination and Seedling Growth of Wheat (Triticum aestivum L.). Ecotoxicology and Environmental Safety, 73, 1982-1987. http://dx.doi.org/10.1016/j.ecoenv.2010.08.041

[8] Jagetiya, B., Soni, A. and Yadav, S. (2013) Effect of Nickel on Plant Water Relations and Growth in Green Gram. Indian Journal of Plant Physiology, 18, 372-376. http://dx.doi.org/10.1007/s40502-013-0053-8

[9] Mishra, S., Srivastava, S., Tripathi, R., Kumar, R., Seth, C. and Gupta, D. (2006) Lead Detoxification by Coontail (Ceratophyllum demersum L.) Involves Induction of Phytochelatins and Antioxidant System in Response to Its Accumulation. Chemosphere, 65, 1027-1039. http://dx.doi.org/10.1016/j.chemosphere.2006.03.033

[10] Tewari, R.K., Kumar, P., Sharma, P.N. and Bisht, S.S. (2002) Modulation of Oxidative Stress Responsive Enzymes by Excess Cobalt. Plant Science, 162, 381-388. http://dx.doi.org/10.1016/S0168-9452(01)00578-7

[11] Cho, U.H. and Park, J.O. (2000) Mercury-Induced Oxidative Stress in Tomato Seedlings. Plant Science, 156, 1-9. http://dx.doi.org/10.1016/S0168-9452(00)00227-2

[12] Qureshi, M.I., Israr, M., Abdin, M.Z. and Iqbal, M. (2005) Responses of Artemisia annua L. to Lead and Salt-Induced Oxidative Stress. Environmental and Experimental Botany, 53, 185-193. http://dx.doi.org/10.1016/j.envexpbot.2004.03.014

[13] Nakano, Y. and Asada, K. (1981) Hydrogen Peroxide Is Scavenged by Ascorbate-Specific Peroxidase in Spinach Chloroplasts. Plant and Cell Physiology, 22, 867-880.

[14] Verma, S. and Dubey, R.S. (2003) Lead Toxicity Induces Lipid Peroxidation and Alters the Activities of Antioxidant Enzymes in Senescing Soybean Leaves. Plant Physiology, 121, 453-461.

[15] Mittler, R. (2002) Oxidative Stress, Antioxidants and Stress Tolerance. Trends Plant Science, 7, 405-410. http://dx.doi.org/10.1016/S1360-1385(02)02312-9

[16] Zhang, F.Q., Wang, Y.S., Lou, Z.P. and Dong, J.D. (2007) Effect of Heavy Metal Stress on Antioxidative Enzymes and Lipid Peroxidation in Leaves and Roots of Two Mangrove Plant Seedlings (Kandelia candel and Bruguiera gymnorrhiza). Chemosphere, 67, 44-50. http://dx.doi.org/10.1016/j.chemosphere.2006.10.007

[17] Jiang, N., Luo, X., Zeng, J., Yang, Z.R., Zheng, L.N. and Wang, S.T. (2010) Lead Toxicity Induced Growth and Antioxidant Responses in Luffa cylindrica Seedlings. International Journal of Agriculture \& Biotechnology, 12, $205-210$.

[18] Godbold, D.L., Horst, W.J.H., Collins, J.C., Thurman, D.A. and Marschner, H. (1984) Accumulation of Zinc and Organic Acids in Roots of Zinc Tolerant and Non-Tolerant Ecotypes of Deschampisia caespitosa. Journal of Plant Physiology, 116, 59-69. http://dx.doi.org/10.1016/S0176-1617(84)80084-X

[19] Zenk, M.H. (1996) Heavy Metal Detoxification in Higher Plants-A Review. Gene, 179, 21-30. http://dx.doi.org/10.1016/S0378-1119(96)00422-2

[20] Rauser, W.E. (1999) Structure and Function of Metal Chelators Produced by Plants: The Case for Organic Acids, Amino Acids, Phytin and Metallothioneins. Cell Biochemistry and Biophysics, 32, 19-48. http://dx.doi.org/10.1007/BF02738153

[21] Sanita di Toppi, L. and Gabbrielli, R. (1999) Response to Cadmium in Higher Plants. Environmental and Experimental Botany, 41, 105-130. http://dx.doi.org/10.1016/S0098-8472(98)00058-6 
[22] Venkataramaiah, N., Ramakrishna, S.V. and Srivathsa, R. (2011) Overexpression of Phytochelatin Synthase (AtPCS) in Rice for Tolerance to Cadmium Stress. Biologia, 66, 1060-1073. http://dx.doi.org/10.2478/s11756-011-0135-X

[23] Ekmekci, Y., Tanyolac, D. and Ayhan, B. (2009) A Crop Tolerating Oxidative Stress Induced by Excess Lead: Maize. Acta Physiologiae Plantarum, 31, 319-330. http://dx.doi.org/10.1007/s11738-008-0238-3

[24] Zaier, H., Ghnaya, T. and Abdelly, C. (2014) Interactions between Lead on Nutrients $\left(\mathrm{Ca}^{2+}, \mathrm{K}^{+}\right.$, N), and Their Consequences on Growth in Sesuvium portulacastrum and Brassica juncea. Journal of Bioremediation and Biodegradation, 5, 243. http://dx.doi.org/10.4172/2155-6199.1000243

[25] Hu, R., Sunc, K., Suc, X., Pana, Y., Zhanga, Y. and Wanga, X. (2012) Physiological Responses and Tolerance Mechanisms to Pb in Two Xerophils: Salsola passerina Bunge and Chenopodium album L. Journal of Hazardous Materials, 205-206, 131-138. http://dx.doi.org/10.1016/j.jhazmat.2011.12.051

[26] Su, Y., Wang, X., Liu, C. and Shi, G. (2012) Variation in Cadmium Accumulation and Translocation among Peanut Cultivars as Affected by Iron Deficiency. Plant and Soil, 363, 1-13.

[27] Wang, C., Tian, Y., Wang, X., Geng, J., Jiang, J., Yu, H. and Wang, C. (2010) Lead-Contaminated Soil Induced Oxidative Stress, Defence Response and Its Indicative Biomarkers in Roots of Vicia faba Seedlings. Ecotoxicology, 19, 1130-1139. http://dx.doi.org/10.1007/s10646-010-0496-x

[28] Sudhakar, C., Syamalabai, L. and Veeranjaneyulu, K. (1992) Lead Tolerance of Certain Legume Species Grown on Lead Ore Tailings. Agriculture, Ecosystems \& Environment, 41, 253-261. http://dx.doi.org/10.1016/0167-8809(92)90114-Q

[29] Fargasova, A. (1994) Effect of Pb, Cd, Hg, As and Cr on Germination and Root Growth of Sinapis alba Seeds. Bulletin of Environmental Contamination and Toxicology, 52, 452-456. http://dx.doi.org/10.1007/BF00197836

[30] Lakshmi, N. (2013) Lead Uptake and Accumulation in Groundnut Crop Grown at Different Soil Lead Amendments. International Research Journal of Environmental Sciences, 2, 27-33.

[31] Romero-Puertas, M.C., Rodriguez-Serrano, M., Corpas, F.J., Gomez, M., Del Rio, L.A. and Sandalio, L.M. (2004) Cadmium-Induced Sub-Cellular Accumulation of $\mathrm{O}_{2}^{-}$and $\mathrm{H}_{2} \mathrm{O}_{2}$ in Pea Leaves. Plant Cell \& Environment, 27, 11221134. http://dx.doi.org/10.1111/j.1365-3040.2004.01217.x

[32] Doke, N. (1983) Involvement of Superoxide Anion Generation in the Hypersensitive Response of Potato Tuber Tissues to Infection with an Incompatible Race of Phytophtora infestans and the Hyphal Wall Components. Physiology and Plant Pathology, 23, 345-357. http://dx.doi.org/10.1016/0048-4059(83)90019-X

[33] Singh, N., Ma, L.Q., Srivastava, M. and Rathinasabapathi, B. (2006) Metabolic Adaptations to Arsenic-Induced Oxidative Stress in Pteris vittata L. and Peris ensiformis L. Plant Science, 170, 274-282. http://dx.doi.org/10.1016/j.plantsci.2005.08.013

[34] Hodges, D.M., Delong, J.M., Forney, C.F. and Prange, R.K. (1999) Improving the Thiobarbituric Acid Reactive Substance Assay for Estimating Lipid Peroxidation in Plant Tissues Containing Anthocyanin and Other Interfering Compounds. Planta, 207, 604-611. http://dx.doi.org/10.1007/s004250050524

[35] Bates, L.S., Waldren, R.P. and Teare, E.D. (1973) Rapid Determination of Free Proline for Stress Studies. Plant and Soil, 39, 205-207. http://dx.doi.org/10.1007/BF00018060

[36] Cakmak, I. and Marschner, H. (1992) Magnesium Deficiency and High Light Intensity Enhance Activities of Superoxide Dismutase, Ascorbate Peroxidise and Glutathione Reductase in Bean Leaves. Plant Physiology, 98, 1222-1227. http://dx.doi.org/10.1104/pp.98.4.1222

[37] Lowry, O.H., Rosebrough, N.J., Farr, A.L. and Randall, R.S. (1951) Protein Measurements with the Folin-Phenol Reagent. Journal of Biological Chemistry, 193, 265-275.

[38] Urbanek, H., Kuzniak-Gebarowska, E. and Herka, K. (1991) Elicitation of Defence Responses in Bean Leaves by Botrytis cinerea Polygalacturonase. Acta Physiologiae Plantarum, 13, 43-50.

[39] Upadhyaya, D., Sankhla, T.D., Davis, N., Sankhla, B.N. and Smith, J. (1985) Effect of Paclobutrazol on the Activities of Some Enzymes of Activated Oxygen Metabolism and Lipid Peroxidation in Senescing Soybean Leaves. Plant Physiology, 121, 453-461. http://dx.doi.org/10.1016/S0176-1617(85)80081-X

[40] Foster, J.S. and Hess, J.L. (1980) Responses of Superoxide Dismutase and Glutathione Reductase Activities in Cotton Leaf Tissue Exposed to an Atmosphere Enriched in Oxygen. Plant Physiology, 66, 482-487. http://dx.doi.org/10.1104/pp.66.3.482

[41] Habig, W.H., Pabst, M.J. and Jakoby, W.B. (1974) Glutathione S-Transferases: The First Enzymatic Step in Mercapturic Acid Formation. Journal of Biological Chemistry, 249, 7130-7139.

[42] Laemmli, U.K. (1970) Cleavage of Structural Proteins during the Assembly of the Head of Bacteriophase T4. Nature, 227, 680-685. http://dx.doi.org/10.1038/227680a0

[43] Beauchamp, C. and Fridovich, I. (1971) Superoxide Dismutase: Improved Assay and Assay Applicable to Acrylamide 
Gels. Analytical of Biochemistry, 44, 276-287. http://dx.doi.org/10.1016/0003-2697(71)90370-8

[44] Birecka, H. (1978) Corn Leaf Isoperoxidase Reaction to Mechanical Injury and Infection with Helminthosporium maydis: Effects of Cycloheximide. Plant Physiology, 61, 561-566. http://dx.doi.org/10.1104/pp.61.4.561

[45] Lee, D.H. and Lee, C.B. (2000) Chilling Stress-Induced Changes of Antioxidant Enzymes in the Leaves of Cucumber: In Gel Enzyme Activity Assays. Plant Science, 159, 75-85. http://dx.doi.org/10.1016/S0168-9452(00)00326-5

[46] Ye, B., Gitler, C. and Gressel, J.A. (1997) A High-Sensitivity, Singlegel, Polyacrylamide Gel Electrophoresis Method for the Quantitative Determination of Glutathione Reductase. Electrophoresis, 246, 159-165.

[47] Akinci, I.E., Akinci, S. and Yilmaz, K. (2010) Response of Tomato (Solanum lycopersicum L.) to Lead Toxicity: Growth, Element Uptake, Chlorophyll and Water Content. African Journal of Agricultural Research, 5, 416-423.

[48] Alkhatib, R., Maruthavanan, J., Ghoshroy, S., Steiner, R., Sterling, T. and Creamer, R. (2011) Physiological and Ultra Structural Effects of Lead on Tobacco. Biologia Plantarum, 56, 711-716. http://dx.doi.org/10.1007/s10535-012-0241-9

[49] Lane, S.D. and Martin, E.S. (1977) A Histochemical Investigation of Lead Uptake in Raphanus sativus. New Phytologist, 79, 281-286. http://dx.doi.org/10.1111/j.1469-8137.1977.tb02206.x

[50] Przymusinski, R., Spychala, M. and Gwozdz, E.A. (1991) Inorganic Lead Changes Growth Polypeptide Pattern of Lupin Roots. Biochemie und Physiologie der Pflanzen, 187, 51-57. http://dx.doi.org/10.1016/S0015-3796(11)80187-3

[51] Cox, R.M. and Hutchinson, T.C. (1981) Multiple and Co-Tolerance in the Grass Deschampsia cespitosa: Adaptation, Preadaptation and “Cost”. Journal of Plant Nutrition, 3, 731-741. http://dx.doi.org/10.1080/01904168109362875

[52] Bharwana, S.A., Ali, S., Farooq, M.A., Iqbal, N., Abbas, F. and Ahmad, M.S.A. (2013) Alleviation of Lead Toxicity by Silicon Is Related to Elevated Photosynthesis, Antioxidant Enzymes Suppressed Lead Uptake and Oxidative Stress in Cotton. Journal of Bioremediation and Biodegradation, 4, 1-11.

[53] Azad, H.N., Shiva, A.H. and Malekpour, R. (2011) Toxic Effects of Lead on Growth and Some Biochemical and Ionic Parameters of Sunflower (Helianthus annuus L.) Seedlings. Current Research Journal of Biological Sciences, 3, 398403.

[54] Zhao, S., Ye, X. and Zheng, J. (2011) Lead-Induced Changes in Plant Morphology, Cell Ultrastructure, Growth and Yields of Tomato. African Journal of Biotechnology, 10, 10116-10124.

[55] Khateeb, A.W. and Al-Qwasemeh, H. (2014) Cadmium, Copper and Zinc Toxicity Effects on Growth, Proline Content and Genetic Stability of Solanum nigrum L., a Crop Wild Relative for Tomato; Comparative Study. Physiology and Molecular Biology of Plants, 20, 31-39. http://dx.doi.org/10.1007/s12298-013-0211-5

[56] Ashraf, M. and Foolad, M.R. (2007) Roles of Glycine Betaine and Proline in Improving Plant Abiotic Stress Resistance. Environmental and Experimental Botany, 59, 206-216. http://dx.doi.org/10.1016/j.envexpbot.2005.12.006

[57] Demirevska-Kepova, K., Simova-Stoilova, L., Stoyanova, Z., Holzer, R. and Feller, U. (2004) Biochemical Changes in Barley Plants after Excessive Supply of Copper and Manganese. Environmental and Experimental Botany, 52, 253266. http://dx.doi.org/10.1016/j.envexpbot.2004.02.004

[58] Li, Y., Song, Y., Shi, G., Wang, J. and Hou, X. (2009) Response of Antioxidant Activity to Excess Copper in Two Cultivars of Brassica campestris spp. chinensis Makino. Acta Physiolgiea Plantarum, 31, 155-162. http://dx.doi.org/10.1007/s11738-008-0216-9

[59] Pirselova, B., Kuna, R., Libantova, J., Moravcikova, J. and Matusikova, I. (2011) Biochemical and Physiological Comparison of Heavy Metal-Triggered Defence Responses in the Monocot Maize and Dicot Soybean Roots. Molecular Biology Reports, 38, 3437-3446. http://dx.doi.org/10.1007/s11033-010-0453-z

[60] Wang, P., Zhang, S., Wang, C. and Lu, J. (2012) Effects of Pb on the Oxidative Stress and Antioxidant Response in a $\mathrm{Pb}$ Bioaccumulator Plant Vallisneria natans. Ecotoxicology and Environmental Safety, 78, 28-34. http://dx.doi.org/10.1016/j.ecoenv.2011.11.008

[61] Lin, Z.F., Nan, N., Lin, G.Z. and Peng, C.L. (2009) In Situ Localisation of Superoxide Generated in Leaves of Alocasia macrorrhiza (L.) Schott under Various Stresses. Journal of Plant Biology, 52, 340-347. http://dx.doi.org/10.1007/s12374-009-9044-8

[62] Apel, K. and Hirt, H. (2004) Reactive Oxygen Species: Metabolism, Oxidative Stress, and Signal Transduction. Annual Review of Plant Biology, 55, 373-399. http://dx.doi.org/10.1146/annurev.arplant.55.031903.141701

[63] Kumar, A., Pradad, M.N.V. and Sytar, O. (2012) Lead Toxicity, Defence Strategies and Associated Indicative Biomarkers in Talinum triangulare Grown Hydroponically. Chemosphere, 89, 1056-1065. http://dx.doi.org/10.1016/j.chemosphere.2012.05.070

[64] Chen, L., Gao, S., Zhu, P., Liu, Y., Hu, T. and Zhang, J. (2014) Comparative Study of Metal Resistance and Accumulation of Lead and Zinc in Two Poplars. Physiologiae Plantarum, 151, 390-405. http://dx.doi.org/10.1111/ppl.12120

[65] Gill, S.S. and Tuteja, N. (2010) Reactive Oxygen Species and Antioxidant Machinery in Abiotic Stress Tolerance in Crop Plants. Plant Physiology and Biochemistry, 48, 909-930. http://dx.doi.org/10.1016/j.plaphy.2010.08.016 
[66] Cho, U.H. and Seo, N.H. (2005) Oxidative Stress in Arabidopsis thaliana Exposed to Cadmium Is Due to Hydrogen Peroxide Accumulation. Plant Science, 168, 113-120. http://dx.doi.org/10.1016/j.plantsci.2004.07.021

[67] Sharma, P. and Dubey, R.S. (2004) Ascorbate Peroxidase from Rice Seedlings; Properties of Enzyme Isoforms, Effects of Stress and Protective Roles of Osmolytes. Plant Science, 167, 541-550. http://dx.doi.org/10.1016/j.plantsci.2004.04.028

[68] Milone, M.T., Sgherri, C., Clijsters, H. and Navari-Izzo, F. (2003) Antioxidative Responses of Wheat Treated with Realistic Concentration of Cadmium. Environmental and Experimental Botany, 50, 265-276. http://dx.doi.org/10.1016/S0098-8472(03)00037-6

[69] Gallego, S.M., Benavides, M.P. and Tomaro, M.L. (1996) Effect of Heavy Metal Ion Excess on Sunflower Leaves: Evidence for Involvement of Oxidative Stress. Plant Science, 121, 151-159. http://dx.doi.org/10.1016/S0168-9452(96)04528-1

[70] Weckx, J.E.J. and Ciljsters, H.M. (1997) Zn Phytotoxicity Induces Oxidative Stress in Primary Leaves of Phaseolus vulgaris L. Plant Physiology and Biochemistry, 35, 405-410.

[71] Nouairi, I., Ammar, W.B., Youssef, N.B., Miled, D.D.B., Ghorbal, M.H. and Zarrouk, M. (2009) Antioxidant Defence System in Leaves of Indian Mustard (Brassica juncea) and Rape (Brassica napus) under Cadmium Stress. Acta Physiologiae Plantarum, 31, 237-247. http://dx.doi.org/10.1007/s11738-008-0224-9

[72] Beladi, M., Kashani, A., Habidi, D., Paknejad, F. and Golshan, M. (2011) Uptake and Effects of Lead and Copper on Three Plant Species in Contaminated Soils: Role of Phytochelatin. African Journal of Agricultural Research, 6, 34833492.

[73] Venkatachalam, P., Srivastava, A.K., Raghothama, K.G. and Sahi, S.V. (2007) Identification of Lead-Regulated Genes by Suppression Subtractive Hybridization in the Heavy Metal Accumulator Sesbania drummondii. Planta, 225, 13531365. http://dx.doi.org/10.1007/s00425-006-0445-3

[74] Baker, A.J.M. and Walker, P.L. (1990) Ecophysiology of Metal Uptake by Tolerant Plants. In: Shaw, A.J., Ed., Heavy Metal Tolerance in Plants: Evolutionary Aspects, CRC Press, Boca Raton, 155-177.

[75] Broyer, T.C., Johnson, C.M. and Paull, R.E. (1972) Some Aspects of Lead in Plant Nutrition. Plant and Soil, 36, 301313. http://dx.doi.org/10.1007/BF01373485 